\author{
Dorota Guttfeld, Monika Linke-Ratuszny \\ Uniwersytet Mikołaja Kopernika w Toruniu \\ gutt@umk.pl, monlin@umk.pl
}

\title{
WARSZTAT PRACY TŁUMACZA LITERATURY: BADANIE ANKIETOWE
}

DOI: http://dx.doi.org/10.12775/RP.2019.009

Zarys treści: Artykuł jest raportem z badania ankietowego przeprowadzonego wśród osób zajmujących się przekładem literackim. Celem badania było stworzenie orientacyjnego obrazu warsztatu pracy i organizacji pracy tłumacza literatury. Pytania dotyczyły sposobu korzystania z komputera, programów do edycji tekstu i poszczególnych ich funkcji, sposobu otrzymywania i wysyłania tekstów, technik stosowanych w trakcie ich poprawiania, a także wymagań odnośnie do ich formatowania.

Słowa kluczowe: przekład literacki, badanie ankietowe, warsztat tłumacza

\section{Badanie warsztatu pracy tłumacza}

Dojęcie warsztatu pracy tłumacza (translator's workstation / workbench) według Harolda Somersa zaczęło się krystalizować w latach 80. XX wieku i już na początku XXI stulecia oprogramowanie do edycji tekstu było wymieniane jako jego podstawowe narzędzie (Somers 2003: 13-15; Hutchins 1998); uwaga badaczy zwróciła się więc ku bardziej zaawansowanym narzędziom CAT, lokalizacji, przekładowi maszynowemu i jego post-edycji, a co za tym idzie, głównie ku przekładowi tekstów użytkowych (por. Fulford i Granell-Zafra 2004, 2005; Sin-Wai 2014); Pisarska i Tomaszkiewicz w 1998 roku wspominają jeszcze o edytorze tekstu (235); Pym i Biau-Gil (2006) czy Sikora (2013) nie widzą już takiej potrzeby.

Jednocześnie te zmiany niekoniecznie znajdują odbicie $\mathrm{w}$ dydaktyce przekładu literackiego; o ile nauczanie przekładu audiowizualnego czy zapoznawanie studentów ze współczesnym rynkiem przekładu specjalistycznego 
zazwyczaj wiąże się z omawianiem używanego przez profesjonalistów oprogramowania, $w$ przypadku tłumaczenia literatury istnienie specyficznego warsztatu i technik pracy nie wydaje się już tak oczywiste i może być traktowane jako kwestia niewymagająca uwagi ${ }^{1}$. Badanie ankietowe wśród tłumaczy literackich, na którym oparty jest niniejszy artykuł, ma na celu stwierdzenie, jak w istocie wygląda warsztat i organizacja pracy tłumacza literatury, oraz wskazanie, czy i w jakim zakresie może się różnić od warsztatu pracy studenta.

Badanie to zainspirowane zostało wynikami ankiety z roku $2016^{2}$, z których wynikało między innymi, że wśród tłumaczy literackich przekład z pliku wypiera przekład z papierowej wersji tekstu źródłowego, a tekst docelowy także w przeważającej liczbie przypadków powstaje w formie elektronicznej. Źródła elektroniczne dominują również nad papierowymi i „osobowymi” (ekspertami, znajomymi tłumaczami), zwłaszcza wśród osób z mniejszym stażem w zawodzie. Komputer, edytor tekstu, a także przeglądarka, umożliwiająca dostęp do stron, społeczności i usług online, stanowią powszechne elementy wyposażenia współczesnego tłumacza literatury, a praca z nimi wymaga specyficznych umiejętności.

W dniach 6-21 kwietnia 2019 przeprowadziłyśmy kolejną ankietę wśród tłumaczy zajmujących się przekładem literatury. Formularz udostępniony był wyłącznie przez Internet, co może istotnie wpływać na profil tłumaczy. Badanie dotyczyło korzystania z komputera i tłumacze musieli korzystać z komputera, aby wziąć w nim udział; natomiast fakt ten nie przesądza o intensywności czy sposobie jego użycia w samym procesie przekładu. Sposób rozsyłania linku do formularza - nie tylko za pomocą mediów społecznościowych, ale też na służbowe i prywatne adresy e-mailowe tłumaczy oraz przez wydawnictwa, które zgodziły się go przesłać tłumaczom - miał sprawić, aby dostępny był nie tylko dla osób, które są bezustannie online i angażują się w życie społeczności tłumaczy w sieci, ale też tych, które e-maila używają np. do przyjmowania zleceń. Większość respondentów to członkowie Stowarzy-

${ }^{1}$ Większość badań nad sytuacją tłumaczy literatury skupia się na aspekcie ekonomicznym ich pracy, formach zatrudnienia, stopniu „widzialności” tłumacza i sytuacji na rynku wydawniczym; zob. np. P. Assouline, La condition du traducteur (2011) czy S. Paszkiet, Report on the Situation of Literary Translators in Poland (2013).

2 Omówionymi szczegółowo w: Guttfeld 2018. Badania z 2016 i 2019 koncentrują się na innych aspektach pracy tłumacza. W 2016 roku chodziło przede wszystkim o ścieżkę kariery, formę współpracy z wydawnictwami i stopień specjalizacji tłumaczy. Wspólne elementy obu ankiet to robocza definicja tłumacza literatury, pytanie o główne źródło utrzymania i o formę, w jakiej tłumacz otrzymuje teksty. 
szenia Tłumaczy Literatury oraz osoby przeglądające forum Stowarzyszenia na Facebooku i polskie forum portalu Proz.com.

\section{Profil respondenta}

Rozbudowaną ankietę, składającą się z 28 pytań, wypełniło 178 respondentów. Językiem ankiety był polski. Sposób rozsyłania formularza powodował, że miały go szansę wypełnić przede wszystkim osoby pracujące w Polsce, choć niekoniecznie posługujące się językiem polskim jako rodzimym. Dlatego pytanie o języki przekładu nie precyzowało kierunku, w jakim respondenci dokonują tłumaczeń pomiędzy polskim a innymi językami: angielskim (101 wskazań), francuskim (23), niemieckim (16), hiszpańskim (16), rosyjskim (11), norweskim (7), włoskim (6), niderlandzkim (5), szwedzkim (5), czeskim (3), arabskim (2), duńskim (2), japońskim (2), katalońskim (2), ukraińskim (2), węgierskim (2), białoruskim (1), słowackim (1), litewskim (1), perskim (1), afrikaans (1), portugalskim (1), fińskim (1), hebrajskim (1), starogreckim (1), łaciną (1). 44 osoby podały więcej niż jeden język (wliczając w to "języki skandynawskie"); w aż 38 przypadkach jednym z kilku języków był angielski. Dominacja angielskiego (w sumie ok. 65\% respondentów) odzwierciedla rynek wydawniczy, ale niewykluczone, że miały na nią jakiś wpływ osoby autorek rozsyłających ankietę, albo fakt, że tłumacze „mniejszych" języków nie znajdują w sieci aż tylu zasobów i grup wsparcia, więc być może mają mniejszą motywację do zrzeszania się i nieco trudniej trafić do nich online.

Na potrzeby ankiety „tłumacz literacki” to osoba wykonująca odpłatnie przekłady tekstów literackich w celu publikacji. Pojęcie to zostało zdefiniowane na wstępie ankiety, w sposób wykluczający przekłady przeznaczone do bezpośredniego wykorzystania w medium, którego specyfika determinuje podejście tłumacza do tekstu, a więc wykonywane na potrzeby filmu, spektakli scenicznych, lokalizacji czy też komiksu. Nie negujemy związków tego typu tłumaczeń z przekładem literackim, ale warsztat tłumaczy, który się nimi zajmują, w znacznym stopniu odzwierciedla potrzeby danego medium i wymaga osobnych badań.

Nie była natomiast brana pod uwagę kwestia, czy dla respondenta przekład tekstów literackich jest głównym źródłem utrzymania, czy zajęciem okresowym, albo równoległym do przekładu tekstów innego typu, czy też np. pracy $w$ redakcji lub na uczelni. Za każdym razem pytania zaznaczały jednak jasno, że dotyczą doświadczeń związanych z przekładem tekstów li- 
terackich. Według deklaracji ankietowanych, przekład literacki stanowił główne źródło utrzymania dla 67 osób (38\%, co obejmowało 3 osoby na różnych etapach wycofywania się z branży), ale aż dla 53 respondentów (30\%) główną pracą była inna aktywność zawodowa związana z literaturą lub językiem, nie licząc przekładu nieliterackiego, który stanowił główne źródło utrzymania dla 25 osób $^{3} .23$ ankietowane osoby deklarowały, że utrzymują się z zupełnie innego, „niejęzykowego” zajęcia. Wśród opcji „innych” pojawiały się też kombinacje przekład + wspólnota majątkowa (2), przekład literacki + emerytura (4). Trzy osoby oszacowały, że przekład literacki stanowi ok. 50\% ich przychodów, a jedna, że przynosi dochody w niewielkim stopniu, nie precyzując jednak swojego głównego zajęcia. Jak widać, przekład literacki w karierach zawodowych częściej łączy się z inną „pracą okołojęzykową" (np. uczeniem języka, recenzowaniem, redakcją, akademickim badaniem literatury) niż z przekładem nieliterackim, który nie występuje tu częściej (14\%) niż traktowane łącznie zajęcia pozajęzykowe (13\%). Sugeruje to, że przekład literacki i nieliteracki są w znacznej mierze rozdzielnymi obszarami.

Ponieważ ankieta dotyczyła nawyków tłumaczy i najczęściej spotykanych praktyk, jeśli praca nad różnymi tekstami i dla różnych zleceniodawców wyglądała bardzo odmiennie, to udzielając odpowiedzi, respondent miał pomyśleć o pięciu ostatnich zleceniach. Pytania można było pomijać, a większość pytań zamkniętych dawała możliwość wyboru odpowiedzi „inne”, która pozwalała na szczegółowy opis danego przypadku, oraz możliwość wyboru kilku opcji, co sprawia, że podawane poniżej liczby nie zawsze sumują się do ogólnej liczby respondentów. Na końcu ankiety respondentom udostępniono też miejsce na komentarze, w których nierzadko tłumaczyli i precyzowali jeszcze swoje odpowiedzi.

Swój staż w dziedzinie przekładu literackiego respondenci szacowali zazwyczaj na kilkadziesiąt lub więcej zleceń zakończonych publikacją: 94 osoby (53\%) wybrały taką opcję z listy, a 3 dalsze podały konkretne liczby w tym przedziale. 43 osoby (24\%) zaznaczyły, że mają na koncie kilkanaście zleceń, a $32(18 \%)$ - kilka. Odpowiedzi „inne” w tej kategorii to zwykle staż podany w latach; dwie osoby tłumaczące głównie poezję miały kłopoty z określeniem liczby wydanych przekładów i samym pojęciem zlecenia w tym przypadku. Ponieważ większość respondentów otrzymała ankietę za pośrednictwem forum albo kontaktowego adresu podanego przez Stowarzyszenie Tłumaczy

${ }^{3}$ Zgodnie z definicją przyjętą na potrzeby ankiety, obejmuje to też kombinację przekład literacki + przekład filmowy, stanowiący główne źródło utrzymania. 
Literatury, warto zaznaczyć, że organizacja ta wymaga od swoich członków trzech opublikowanych przekładów, zasadniczo publikacji zwartych.

Powyższe pytanie zamykało pierwszą część ankiety, która nie zawierała bardziej szczegółowej „metryczki”. Jako że badanie adresowane było do stosunkowo wąskiego środowiska, zebranie typowo demograficznych danych o wieku, płci czy miejscu zamieszkania respondentów mogłoby - w połączeniu z podanymi przez nich kombinacjami języków czy typami przekładanych tekstów - zbytnio ułatwić identyfikację poszczególnych osób i naruszyć ich poczucie anonimowości, zakłócając odpowiedzi na niektóre pytania (np. dotyczące współpracy z redaktorami).

\section{Warsztat tłumacza literatury}

Jak już wspomniano, badanie z 2016 wskazywało, że najpowszechniej wykorzystywane są źródła elektroniczne, co obejmuje słowniki i inne materiały dostępne online, a także wyszukiwarkę funkcjonującą jako namiastka korpusu językowego ${ }^{4}$. Sugeruje to pośrednio, że nawet jeśli tłumacz nie przekłada na komputerze, to komputer towarzyszy mu w trakcie przekładu. Badanie z 2019 miało przynieść więcej szczegółów na temat roli komputera w pracy tłumacza i sposobu jego wykorzystania, a także innych elementów warsztatu.

W odpowiedzi na pytanie o sprzęt, z jakiego korzystają zazwyczaj przy tłumaczeniu tekstu literackiego, 130 respondentów (74\%) wskazało laptop, 42 respondentów (24\%) używa zazwyczaj komputera stacjonarnego, 3 osoby korzystają z obu (na raz albo w różnych miejscach lub fazach przekładu), a jednej było to obojętne, co sugeruje, że również zdarzało się jej korzystać z obu typów komputerów. Laptop nie jest przy tym wykorzystywany do szczególnie częstego przenoszenia pracy poza dom (tylko 22 respondentów zaznaczyło, że często tłumaczy poza domem, 53 nie robi tego nigdy), choć istotne, że daje on taką możliwość (100 osobom, co stanowi 57\% odpowiadających na to pytanie, tłumaczenie poza domem się zdarza, chociaż rzadko). W podróży tylko jedna osoba tłumaczy „zawsze”, 25 często, 94 rzadko, 53 nigdy. O ile przeniesienie się z laptopem i warsztatem pracy poza dom (np. do biblioteki) nie jest częste, o tyle przeniesienie pracy na obcy sprzęt elektroniczny jest prawie niespotykane: tylko 3 osobom zdarza się to często, 34 rzadko, a aż 135 (78\%) nigdy nie tłumaczy na cudzym komputerze. Ponieważ dostęp do źródeł internetowych zależy tylko od ich znajomości i posiadania połączenia

${ }^{4}$ Co do tej ostatniej koncepcji, por. Austermuehl 2012. 
z siecią, są one osiągalne z praktycznie każdego komputera. Tłumacza literackiego nie obowiązują też zwykle zasady tajności, a udostępnienie plików czy przeniesienie ich na inny komputer nie jest technicznie trudne; wynik ten świadczy zapewne o organizacji regularnej pracy w domu, a prawdopodobnie też o daleko posuniętej personalizacji laptopa jako warsztatu pracy.

W kolejnym pytaniu respondenci wskazywali, jak często korzystają z konkretnych możliwości komputera. Najważniejszy okazał się oczywiście Internet, z którego tłumacząc tekst literacki, tylko 3 respondentów korzysta rzadko, natomiast 37 robi to często, a 137 (77\%) zawsze. Druga z kolei była opcja sprawdzania pisowni i gramatyki, dostępna w większości programów do edycji tekstu, z której 18 osób nie korzysta nigdy, 16 rzadko, 44 często, a 96 (55\%) zawsze. Co ciekawe, tłumacze dość niechętnie korzystają z „firmowych” słowników synonimów, w które wyposażone są zazwyczaj programy do edycji tekstu, natomiast stosunkowo częste jest korzystanie $\mathrm{z}$ innych zainstalowanych słowników.

\begin{tabular}{|l|c|c|c|c|}
\hline $\begin{array}{l}\text { Czy tłumacząc tekst literacki, korzysta } \\
\text { Pan(i) z... }\end{array}$ & Nigdy & Rzadko & Często & Zawsze \\
\hline zainstalowanych słowników & 45 & 24 & 45 & 57 \\
\hline wbudowanego słownika synonimów & 91 & 37 & 29 & 6 \\
\hline tłumaczenia maszynowego & 130 & 20 & 9 & 1 \\
\hline narzędzi CAT & 129 & 22 & 8 & 5 \\
\hline
\end{tabular}

Biegłe posługiwanie się Internetem leży też u podstaw umiejętności, które zdaniem respondentów są szczególnie przydatne początkującym tłumaczom, o czym świadczą dwie pierwsze pozycje w poniższej tabeli. Dostępne w tym pytaniu opcje dotyczyły wyłącznie „technicznych” aspektów pracy tłumacza, w odróżnieniu od kompetencji językowych czy kulturowych.

${ }^{5}$ Wobec znacznej liczby osób wykonujących równolegle inne zawody, niewykluczone, że część respondentów woli korzystać ze stałego sprzętu nie ze względu na swoje potrzeby jako tłumaczy, ale ponieważ ma na nim również pliki czy aplikacje niezbędne do innych celów zawodowych. W każdym razie stałe miejsce pracy, ze sprawdzonym łączem z Internetem i w zasięgu domowej biblioteki, wydaje się komfortem i bezpieczeństwem, z którego tłumaczom literackim trudno rezygnować, mimo teoretycznej możliwości pracy mobilnej, jaką zapewnia laptop, a tym bardziej praca na plikach dostępnych online. 


\begin{tabular}{|l|c|}
\hline \multicolumn{2}{|l|}{ Które z poniższych umiejętności niezwiązanych bezpośrednio z językiem uważa Pan(i) } \\
za szczególnie przydatne dla początkującego tłumacza? \\
\hline znajomość słowników i poradni poprawnościowych dostępnych w sieci & 154 \\
\hline umiejętność formułowania zapytań w przeglądarce internetowej & 42 \\
\hline umiejętność korzystania z bibliotek i źródeł papierowych & 117 \\
\hline znajomość forów, portali i grup dla tłumaczy & 92 \\
\hline umiejętność ergonomicznej organizacji pracy na komputerze & 64 \\
\hline umiejętność przeglądania dużych ilości tekstu & 63 \\
\hline umiejętność ergonomicznej organizacji stanowiska pracy & 46 \\
\hline znajomość zaawansowanych funkcji programów do edycji tekstu & 29 \\
\hline
\end{tabular}

Należy zauważyć, że ze względu na sposób rozprowadzania ankiety rola sieciowych forów, portali i grup tłumaczy może być przeszacowana, bo częściowo właśnie tą drogą można było natrafić na formularz. Na uwagę zasługuje niska pozycja znajomości zaawansowanych funkcji programów do edycji tekstu jako priorytetu młodego tłumacza. Rzeczywiście, w jednym $\mathrm{z}$ dalszych pytań okazuje się, że funkcje zaawansowane używane są stosunkowo rzadko, a spora grupa tłumaczy w ogóle się bez nich obchodzi (co nie oznacza, że nie są przydatne dla osób z nich korzystających).

Wśród oprogramowania do edycji tekstu zdecydowanie dominuje MS Word (pakiet MS Office), którego używa 146 respondentów (82\%).

\begin{tabular}{|l|c|}
\hline Z jakich programów do edycji tekstu korzysta Pan(i), ttumacząc tekst literacki? \\
\hline MS Word (pakiet MS Office) & 146 \\
\hline Libre Office Writer (pakiet Libre Office) & 16 \\
\hline Open Office Writer (pakiet Open Office) & 7 \\
\hline Apple Pages (pakiet IWork) & 5 \\
\hline Programy CAT & 2 (Trados, MemoQ) \\
\hline Google Docs & 1 \\
\hline
\end{tabular}

Tylko jedna osoba korzysta w pracy zawodowej z dokumentów Google jako głównego edytora tekstu. Warto zauważyć, że mimo iż spora grupa tłumaczy literatury łączy tę pracę z przekładem tekstów nieliterackich, w którym bardzo rozpowszechnione jest korzystanie z narzędzi CAT, tylko 2 osoby stosują te programy również w tym przypadku. Jedna osoba zaznaczyła opcję „nie korzystam z edytora”; ma ona na koncie kilkanaście zleceń, zajmuje się przekładem prozy głównego nurtu i literatury faktu. Tłumacząc, używa lap- 
topa, ale z dalszych odpowiedzi wynika, że tłumaczy na papierze, chociaż korektę przeprowadza już w pliku.

Spośród funkcji programu do edycji tekstu tłumacze najczęściej deklarowali korzystanie z automatycznego zliczania liczby słów i znaków, co zazwyczaj związane jest $\mathrm{z}$ wyceną tłumaczenia. W przypadku pozostałych funkcji pojawiała się już duża (a czasem nawet większościowa) grupa osób, które nigdy z nich nie korzystają

\begin{tabular}{|l|c|c|c|c|}
\hline $\begin{array}{l}\text { Czy - tłumacząc tekst literacki - w swo- } \\
\text { im programie do edycji tekstów korzysta } \\
\text { Pan(i) z... }\end{array}$ & Zawsze & Często & Rzadko & Nigdy \\
\hline opcji statystycznych dokumentu & 102 & 41 & 14 & 11 \\
\hline opcji definiowania stylów & 25 & 22 & 44 & 72 \\
\hline $\begin{array}{l}\text { opcji tworzenia indeksów, wykazu źródeł, } \\
\text { oznaczania cytatów }\end{array}$ & 13 & 32 & 50 & 72 \\
\hline $\begin{array}{l}\text { opcji porównywania różnych wersji doku- } \\
\text { mentu }\end{array}$ & 7 & 27 & 68 & 66 \\
\hline własnych skrótów klawiaturowych & 18 & 26 & 40 & 75 \\
\hline opcji podziału okna edytora & 13 & 24 & 47 & 81 \\
\hline $\begin{array}{l}\text { opcji tworzenia spisu treści / planu doku- } \\
\text { mentu }\end{array}$ & 6 & 18 & 48 & 90 \\
\hline opcji tworzenia własnych glosariuszy & 8 & 22 & 39 & 99 \\
\hline $\begin{array}{l}\text { zaawansowanych opcji wyszukiwania, } \\
\text { makr, wyrażeń regularnych }\end{array}$ & 8 & 12 & 42 & 103 \\
\hline $\begin{array}{l}\text { Czy tłumacząc tekst literacki, korzysta } \\
\text { Pan(i) z... }\end{array}$ & zawsze & często & rzadko & nigdy \\
\hline kilku ekranów na raz & 22 & 30 & 32 & 80 \\
\hline podstawek / uchwytów na dokumenty & 19 & 29 & 42 & 77 \\
\hline
\end{tabular}

Warto zwrócić uwagę na względnie małą popularność opcji podziału okna edytora, która jest przydatna przede wszystkim w przypadku pracy w tym samym programie z dwoma plikami, zawierającymi tekst źródłowy i docelowy. Również korzystanie z kilku ekranów na raz ułatwia przede wszystkim przekład z pliku do pliku, natomiast podstawki lub uchwyty

${ }^{6}$ Być może część z opcji, których dotyczyły pytania, nazywa się różnie w różnych programach i wersjach językowych programów, więc mogły nie zostać przez respondentów rozpoznane i otrzymać zaniżoną liczbę wskazań; ponieważ jednak, jak to już omówiono, najpowszechniej używany jest pakiet MS Office, a Libre Office i Open Office są jego dość wiernymi kopiami, nie powinien to być znaczący efekt. 
sprawdzają się głównie w przypadku tłumaczenia z papieru do pliku, chociaż można też umieszczać w nich źródła lub notatki.

\section{Przydatne umiejętności i techniki pracy}

Oprócz szacowania, jak często korzystają z funkcji i usprawnień podanych na liście zamkniętej, w odpowiedzi na pytanie otwarte („Czy są jakieś akcesoria, funkcje i triki, dzięki którym szczególnie usprawnia Pan(i) swoją pracę?”) respondenci opisali wiele innych sposobów, którymi ułatwiają sobie proces przekładu. Można je zebrać w kilka grup tematycznych: organizację i ergonomię; w wrowadzanie i odczyt tekstu; zabezpieczanie rezultatów pracy.

Przede wszystkim badani podkreślali wagę efektywnej organizacji czasu pracy, przewidywania i monitorowania jej postępów. Opisywane przez nich techniki i usprawnienia dotyczyły umiejętnego podziału materiału na partie, szacowania tempa pracy i terminów ukończenia poszczególnych etapów (co ułatwiają specjalistyczne aplikacje albo specjalnie przygotowane arkusze Excela), a następnie trzymania się wyznaczonych norm pracy. W tym z kolei pomagają blokady różnych „rozpraszaczy”, na które łatwo natknąć się, korzystając z Internetu (np. mediów społecznościowych), ale też aplikacje i gadżety do wyznaczania regularnych przerw od pracy przy komputerze, pozwalających zachować wydajność (np. czasomierze, służące do stosowania techniki Pomodoro). Oprócz usuwania „przeszkadzaczy”, respondenci wymieniali różnorodne „wspomagacze”, od rozmaitych podkładek i podstawek, poprawiających ergonomię stanowiska pracy, po ogrzewacze i masażery.

Druga grupa opisów dotyczyła dostosowania do potrzeb tłumacza klawiatury i myszki obsługiwanego komputera. Respondenci zauważają, że zewnętrzna klawiatura ułatwia ergonomiczne korzystanie z laptopa, a poznanie albo stworzenie własnych skrótów klawiaturowych (a nawet przypisanie przydatnych funkcji do przycisków myszki) znacznie przyspiesza pracę. Niektórzy zachęcali do tworzenia glosariuszy i dodawania terminów do autokorekty, co umożliwia ich szybsze wprowadzanie (przydatne choćby w przypadku nazw własnych).

Co do czytania tekstu, często pojawia się zalecenie stosowania kilku ekranów, na których można wygodnie rozmieścić wiele plików. Pojawiały się rady, by najpierw pozyskać takie pliki w formacie łatwym do edycji za pomo-

7 Jednym z niewielu źródeł, które choćby krótko poruszają tę tematykę w przypadku przekładu literackiego, jest Landers 2001: 180-183 (podrozdział Workspace and work time). 
cą programów do optycznego rozpoznawania tekstu (OCR). Do sczytywania tekstu niektórzy respondenci zalecają wykonanie wydruku albo wykorzystanie czytnika. Pracując w pliku, warto stosować spójny system oznaczania „rybek" i innych ważnych miejsc; na papierze podobną funkcję mogą spełniać zakładki. Podawano również propozycje źródeł, które można wykorzystać w pracy: słowników, korpusów, glosariuszy, ale też kontaktów ze znajomymi tłumaczami, czy innych pomocy (np. schematów metrycznych wierszy).

Ostatnia, bardzo liczna grupa uwag dotyczy konieczności regularnego wykonywania kopii bezpieczeństwa i archiwizowania plików (również za pomocą aplikacji umożliwiających dzielenie plików między urządzeniami).

Podobnych wyników dostarczyło pytanie, w którym respondenci zostali poproszeni o namysł nad technicznymi aspektami procesu przekładu, na które szczególnie warto uczulić początkujących tłumaczy. Wskazówki najczęściej dotyczyły tworzenia kopii zapasowych (aż 20 wzmianek); ogólnej znajomości programu, w którym się tłumaczy (12, w tym 3 uwagi na temat programów CAT); ergonomii miejsca pracy (11) i takiej jej organizacji, aby starczyło czasu na autoredakcję, dokładność i poprawność (10); a także umiejętności korzystania ze słowników i, bardziej ogólnie, znajdowania źródeł w Internecie (8), w tym krytycyzmu wobec źródeł, zwłaszcza internetowych $(7)^{8}$. Dalszych 7 uwag dotyczyło używania konkretnych opcji programów do edycji tekstu i wymogów formatowania. 4 osoby wspominały o współpracy $\mathrm{z}$ wydawcą, korektą, redakcją i konieczności negocjacji umowy, 3 zalecały naukę pisania bezwzrokowego.

Warte uwagi są bardzo rozbieżne opinie respondentów co do technicznych i organizacyjnych umiejętności młodych kandydatów na tłumaczy, od uwag, że na pewno wszystko powyższe wiedzą, do komentarzy, że jest to ich pięta achillesowa: „Z mojego doświadczenia wynika, że im młodsza osoba, tym słabsza znajomość programów do edycji tekstów (...) spotkałam się już $\mathrm{z}$ wcięciami akapitowymi wprowadzanymi za pomocą spacji, z nieznajomością terminu »interlinia«, $\mathrm{z}$ niekorzystaniem $\mathrm{z}$ wbudowanych narzędzi do sprawdzania pisowni”; inna osoba postuluje, żeby położyć nacisk na proste kwestie: „odróżnianie łącznika, półpauzy i myślnika; likwidowanie podwójnych spacji; nieużywanie tabulatora". Co do konkretnych funkcji, wspomniany zostaje „[t]ryb śledzenia zmian, komentarzy itd. - cała strona techniczna przy redakcji książki”. Pojawiają się też uwagi co do samodyscypliny i organizacji pracy; respondenci podkreślają, jak istotna jest „[u]miejętność dobrej organizacji projektu - drzewko katalogów, nazewnictwo poszczególnych

${ }^{8}$ Dwie ostatnie kwestie jako podstawowe kompetencje tłumacza w: Austermuehl 2013. 
wersji przekładu i tekstu w trakcie redakcji” czy „[o]kreślanie wiarygodności źródeł (...) Np. korpus tekstów w słowniku języka polskiego PWN zawiera wyrażenia niepoprawne", których nie można bezrefleksyjnie powielać.

\section{Praca w pliku}

Już badanie z 2016 sygnalizowało, że tekst źródłowy tłumacze najczęściej otrzymują w formie pliku; w 2019 dominacja plików stała się zdecydowana. W formie papierowej tekst otrzymuje zazwyczaj 17 ankietowanych osób (mniej niż 10\%), 43 (24\%) dostaje go zwykle w wersji papierowej i elektronicznej, podczas gdy aż 103 (58\%) - zazwyczaj w elektronicznej. Dwie osoby stwierdziły, że trudno im oszacować, która forma jest obecnie częstsza, ale zdarzały się uwagi stwierdzające wyraźną zmianę w kierunku pliku. Dwie osoby zadeklarowały, że samodzielnie zdobywają tekst źródłowy, więc nie ma tu w ogóle mowy o jego „otrzymywaniu”. Format, w jakim tłumacz otrzymuje tekst, nie musi być przy tym tożsamy z formą tekstu, na której pracuje, o czym świadczy polecanie początkującym tłumaczom programów OCR.

$\mathrm{Na}$ format PDF padło 147 wskazań (83\%), co świadczy o tym, że jest on zdecydowanie najczęściej spotykany; 21 osób wskazało pliki DOC(X) oraz (łącznie 4 wskazania) EPUB, MOBI i inne formaty specyficzne dla konkretnych typów tekstów, jak pliki graficzne z reprodukcjami starodruków. Dominacja plików PDF tłumaczy, dlaczego niekoniecznie przydatna jest funkcja porównywania plików czy podziału okna w programach do edycji tekstu: po prostu tekst docelowy tworzy się w innym programie niż służący do odczytu pliku źródłowego (chyba że tłumacz rzeczywiście poświęci czas na jego konwersję). Zaletą pliku PDF jest „większa szansa, że to ostateczna wersja”. Dosyłanie i podmienianie tekstu źródłowego przez zleceniodawcę już w trakcie tłumaczenia jest niewątpliwie uciążliwą konsekwencją przejścia od wersji papierowych tekstu źródłowego do elektronicznych. Tego typu sytuacja „zdarza się, chociaż niezbyt często" aż 86 respondentom, dalszym 4 „dosyć często”, a kolejne 3 osoby opisały rzadkie przypadki, kiedy im również się to przytrafiło; dla porównania, 83 osoby (47\%) zaznaczyły, że dostają tekst w całości i nie następują w nim żadne zmiany.

Ponieważ nie wszyscy wydawcy zaznaczają wprowadzone zmiany, a format PDF utrudnia automatyczne porównanie dokumentów, do listy umiejętności tłumacza warto na pewno dodać sprawne przeszukiwanie obszernego tekstu i wprowadzanie zmian w zaawansowanym już przekładzie bez naruszania jego spójności. W trakcie kolejnych faz przekładu dobrze też umieć 
wyszukać miejsca wymagające korekty. Usprawnieniu tego procesu mogą służyć różnorakie oznaczenia w tekście. Tylko 11 osób stwierdziło, że nie zaznacza w tekście fragmentów, do których trzeba jeszcze wrócić; pozostali nie polegają na pamięci, stosując kolory (123), komentarze w pliku (64), wybrane, łatwe do znalezienia ciągi znaków (ukośniki, małpę, znaki zapytania, nawiasy kwadratowe) albo pogrubioną czcionkę lub podkreślenie (łącznie 42 wskazania). Przy pracy w obszernym pliku przydatna może się więc okazywać opcja przeskakiwania do kolejnego komentarza lub zaawansowana opcja szukania, pozwalająca znajdować konkretny kolor lub formatowanie tekstu. Dla porównania, tylko 3 osoby zaznaczyły, że na tym etapie pracują na papierze (jedna z nich przenosi się na papier „w drugim czytaniu”). Papier częściej przydaje się do robienia notatek w trakcie przekładu: $\mathrm{w}$ tej formie notuje 68 osób (38\%). 15 osób notatek nie potrzebuje, natomiast 95 osób (53\%) również i z tym przeniosło się jednak do plików: albo tych samych, w których powstaje przekład (59), albo oddzielnych (36). 3 osoby notują i w formie tradycyjnej, i na komputerze, co dobrze ilustruje szczegółowy opis: „robię notatki w trzech postaciach: najbardziej bieżące, na następny dzień, do zastanowienia - na papierowej wersji tekstu lub na karteczkach, które kładę przy komputerze; cytaty, źródła do wyszukania itp. - w osobnym dokumencie notatnika; uwagi bezpośrednio dotyczące tekstu, które mogą się stać uwagami dla redakcji - w komentarzach".

Jeśli notatki powstają w tym samym pliku (co jest dość częste), naturalnie trzeba je na koniec wyszukać i usunąć z tekstu. Może to być o tyle złożone zadanie, że - jak wskazuje kolejna partia odpowiedzi, ostatnie większe zmiany w tekście przed jego sprawdzeniem i wysyłką dotyczą elementów rozproszonych po tekście: upraszczania, ujednoznaczniania i „rozjaśniania” treści (76), długości, rytmu i sposobu łączenia zdań (66), a także innych wymienianych przez tłumaczy usterek stylistycznych (rymów, powtórzeń, niezręczności). 65 osób zaznaczyło, że na ostatnim etapie najczęściej zmieniają terminy czy nazwy własne; tyle samo zmienia wówczas tytuły i inne kluczowe frazy, które muszą dobrze brzmieć (65). Ostatnie poprawki dotyczą też humoru, gier słownych, fragmentów wieloznacznych (60) i poziomu formalności lub stylizacji tekstu (52), a znacznie rzadziej elementów kulturowych (27), a także innych kwestii: partii rymowanych, wierszy (2), aparatu bibliograficznego, cytatów, po które trzeba się udać do biblioteki, oraz ogólnie poprawności językowej i stylistycznej, literówek, rozmaitych trudnych miejsc (10) i kwestii technicznych: formatowania tekstu, podziału na strony. Powyższe odpowiedzi ilustrują wartość prowadzonych systematycznie notatek i oznaczeń w pliku: o ile dosyć łatwo podmienić w niemal ukończonym tekście nazwę własną 
czy tytuł rozdziału, o tyle miejsca niejasne czy wymagające zmiany stylistycznej znacznie łatwiej odnaleźć, jeśli tłumacz oznaczy je na bieżąco. Natomiast sposób traktowania kwestii kulturowych (zakładając, że tłumacze w ogóle poświęcają uwagę temu zagadnieniu) najwyraźniej ustalany jest na stosunkowo wczesnym etapie, w przeciwieństwie na przykład do rejestru języka, który dość często zdarza się tłumaczom zmieniać do ostatniej chwili.

Z wcześniejszych odpowiedzi można wywnioskować, że tekst źródłowy to zwykle plik (z reguły PDF), a sam przekład także powstaje w pliku (zwykle MS Word), ale tylko 22 tłumaczy zaznaczyło, że okno z przekładem (i oryginałem, jeśli również jest w postaci cyfrowej) to jedyne, co mają zazwyczaj otwarte na komputerze w trakcie przekładu. Większość (106, czyli 60\% udzielających odpowiedzi) przy pracy w pliku ma otwartych naraz jeszcze przynajmniej kilka dokumentów, zakładek przeglądarki lub programów, a 47 szacuje, że jest ich zwykle kilkanaście (pojawiła się nawet odpowiedź „kilkadziesiąt”). Będąc online, trudno zresztą czasami oddzielić od siebie pracę i inne czynności, albo różne rodzaje pracy, a przecież wielu respondentów łączy przekład literacki z innym zawodem; w tym kontekście zrozumiała staje się rola drugiego monitora oraz konieczność dobrej organizacji pracy i eliminacji dodatkowych „rozpraszaczy”. Być może prowadzenie notatek w tym samym pliku, w którym powstaje przekład, jest też formą obrony przed dalszym mnożeniem dokumentów. Po tak dużej liczbie otwartych okien, których nawet przy dobrym monitorze nie da się wygodnie rozłożyć obok siebie na stałe, trzeba umieć się sprawnie poruszać. Większość tłumaczy (129, czyli 73\%) z reguły przełącza się między oknami, podczas gdy 29 udaje się zwykle rozmieścić je tak, żeby były dostępne jednocześnie. 8 osób stosuje oba systemy.

Przy takiej liczbie działających jednocześnie programów i zakładek łatwo może się zdarzyć, że któraś z aplikacji przestanie reagować na polecenia. Już wśród rad dla początkujących powtarzały się regularnie uwagi o konieczności zapisu pracy, niepolegania na automatycznym zapisie („sejw po każdym akapicie") albo używania do tego celu specjalnych makr i aplikacji. Kopie zapasowe tłumacze najczęściej wykonują, wysyłając tekst do siebie e-mailem (95 odpowiedzi, 53\%), co czyni go też dostępnym z innych urządzeń w razie poważniejszej awarii. Kolejną popularną metodą jest zapis na nośnikach zewnętrznych (87) oraz w chmurze (68); co ciekawe, tę ostatnią technikę stosuje nawet ta jedyna osoba, która tłumaczy za pomocą Google Docs, najwyraźniej nie dowierzając automatycznemu zapisowi albo chroniąc się przed ewentualną odmową dostępu do pliku, a inny respondent opisuje, że prowadzi wręcz dwie archiwizacje, automatyczną i ręczną, w dwóch różnych chmurach. Inne sposoby to zapis lub wysłanie pliku na kilka urządzeń (46), tworzenie kilku 
kopii pliku na tym samym urządzeniu (37), albo zapis postępu w kolejnych plikach zamiast w jednym (19). Jedna osoba polega na wydruku, jedna odpowiedziała też: „Nie zabezpieczam i nie archiwizuję; z innych odpowiedzi wynika, że być może tłumaczy głównie krótsze teksty.

\section{Adiustacja, korekta, redakcja}

Kolejne pytanie dotyczyło zakresu odpowiedzialności tłumacza za wstępne przygotowanie tekstu do druku. W 95 przypadkach (53\%) tekst wysyłany do zleceniodawcy nie jest całkowicie „czysty”, zawiera bowiem komentarze tłumacza $\mathrm{z}$ uwagami. W 26 przypadkach sam tekst na tym etapie zawiera jeszcze oznaczenia tłumacza (np. kolory albo umieszczone w samym tekście komentarze, zaznaczone w umowny sposób). 2 osoby wysyłają zazwyczaj komentarze w osobnym pliku. Plik gotowy do wysyłki jest też zwykle częściowo dostosowany do wymogów wydawniczych. Jak widać poniżej, tłumacz musi umieć wprowadzać poprawnie wszystkie znaki interpunkcyjne odpowiednie do języka, natomiast już niekoniecznie formatować tekst według wytycznych wydawnictwa.

\begin{tabular}{|l|l|}
\hline Plik, który przesyła Pan(i) do zleceniodawcy, ma zwykle... \\
\hline sformatowane wg zaleceń myślniki i półpauzy & 85 \\
\hline ustawione wg zaleceń wcięcia akapitowe & 75 \\
\hline sformatowane wg zaleceń cudzysłowy (proste / drukarskie) & 68 \\
\hline zdefiniowane wg zaleceń style & 39 \\
\hline powstawiane twarde spacje i znaki podziału & 31 \\
\hline
\end{tabular}

Z komentarzy tłumaczy wynika, że istnieją dwie podstawowe sytuacje: brak formatowania (zdarzają się wręcz zalecenia, żeby unikać prób samodzielnego formatowania tekstu) lub brak wytycznych, co niekoniecznie jest tożsame z powyższym, ponieważ wielu tłumaczy stosuje oczywiste dla siebie reguły, ale zwykle nie ubiega się aktywnie o wskazówki wydawnictwa. 3 osoby podkreśliły, że jeśli dostają jakieś wytyczne, starają się do nich zastosować, albo robią „,wszystko, czego dany tekst wymaga”, ale tylko jedna napisała, że pyta nowego zleceniodawcę o ewentualne niestandardowe oczekiwania. Zazwyczaj wystarcza domniemanie minimalnego formatowania, o czym świadczą uwagi w rodzaju: „,nigdy nie przesłano mi zaleceń od wydawcy”; „formatowanie standardowe”; „zgodne z oryginałem oraz z zasadami języ- 
ka docelowego”; „proszą o unikanie jakiegokolwiek formatowania”; „twarde spacje wytknięto mi jako utrudnienie dla redaktora".

Ostatnia grupa pytań w ankiecie dotyczyła dalszych losów tekstu. 7 respondentów stwierdziło, że po odesłaniu nie dostaje go już w wersji poprawionej przez korektę lub redakcję; jak zaznaczyła jedna osoba, jest to tendencja, która się ostatnio nasila. Pozostali otrzymują poprawki w różnych formach (można było zaznaczyć kilka opcji): 13 osób otrzymuje je w wersji papierowej, 50 wprowadzone do tekstu tak, że jeśli zgadzają się z uwagami, nie muszą już nic robić, $86 \mathrm{w}$ pliku, ale wprowadzone w postaci komentarzy z sugestiami, które tłumacz ma sam wprowadzić, wreszcie najwięcej (120, $68 \%$ ) otrzymuje poprawki w pliku w trybie śledzenia zmian, do każdorazowej akceptacji, więc po kolei zatwierdza je lub odrzuca. Ciekawym wariantem jest otrzymywanie poprawek wprowadzonych w trybie śledzenia zmian, ale z prośbą o odsyłanie ich bez akceptacji, jeżeli tłumacz się z nimi zgadza, albo ręczne ich skreślanie lub wpisywanie pierwotnej wersji, jeśli chce je odrzucić. Cały proces może przebiegać wieloetapowo, a zmiany pojawiać się w różnej formie zależnie od etapu; ponadto oprócz poprawek w tekście w komentarzach nierzadko toczą się dyskusje z redaktorami. Choć forma i jakość tej współpracy to kwestia bardzo indywidualna, na podstawie odpowiedzi respondentów można uszeregować typy wyprowadzanych przez redakcję poprawek od zwykle najmniej do najbardziej kontrowersyjnych. Jak widać poniżej, respondenci zazwyczaj bez wahania przyjmują poprawki w kwestiach językowych i terminologicznych, ale już na problemy stylistyczne i kulturowe tłumacze często zapatrują się inaczej niż redakcja (co nie znaczy, że formalnie odrzucają poprawki). Ponieważ, jak widać, kontrowersyjne poprawki (a co za tym idzie, potencjalne modyfikacje w tekście) mogą dotyczyć aspektów rozsianych po całym tłumaczeniu i wiązać się z dalekosiężnymi zmianami, tłumacz musi umieć je sprawnie przeglądać i negocjować.

\begin{tabular}{|l|c|c|l|l|}
\hline $\begin{array}{l}\text { Jak Pan(i) ocenia otrzymywane } \\
\text { komentarze, sugestie i poprawki } \\
\text { dotyczące... }\end{array}$ & $\begin{array}{l}\text { Zwykle } \\
\text { się z nimi } \\
\text { zgadzam }\end{array}$ & $\begin{array}{l}\text { Częściej } \\
\text { się z nimi } \\
\text { zgadzam } \\
\text { niż nie } \\
\text { zgadzam }\end{array}$ & $\begin{array}{l}\text { Częściej } \\
\text { sięz nimi } \\
\text { nie zga- } \\
\text { dzam niż } \\
\text { zgadzam }\end{array}$ & $\begin{array}{l}\text { Zwykle się } \\
\text { z nimi nie } \\
\text { zgadzam }\end{array}$ \\
\hline poprawności językowej & 54 & 106 & 13 & 2 \\
\hline poprawności terminologicznej & 35 & 102 & 28 & 9 \\
\hline stylu przekładu & 22 & 93 & 40 & 16 \\
\hline przekładu aspektów kulturowych & 18 & 87 & 51 & 13 \\
\hline
\end{tabular}




\section{Wnioski na potrzeby dydaktyki}

Na podstawie wyników ankiety warto zastanowić się nad umiejętnościami spoza językowego i kulturowego meritum przekładu, jakich wymaga tłumaczenie literackie, a na jakie niekoniecznie zwraca się uwagę $\mathrm{w}$ trakcie zajęć $\mathrm{z}$ tego zakresu. Wbrew pozorom również $\mathrm{w}$ przekładzie literackim mogą pojawiać się specyficzne wyzwania, wykraczające poza wachlarz umiejętności, które student nabywa, tworząc innego rodzaju przekłady czy prace zaliczeniowe.

Jedną z nich może być właśnie umiejętność negocjowania i uzasadniania obranego kierunku przekładu we współpracy z innymi uczestnikami całego procesu, z którego wieloetapowym przebiegiem warto zapoznać studentów. Od strony technicznej dialog odbywa się zazwyczaj w plikach z przekładem, za pomocą komentarzy i opcji korekty; tylko pojedyncze uwagi dotyczyły komentarzy odredakcyjnych przesyłanych w mailach albo ustnej dyskusji z redaktorem.

O ile respondenci potwierdzają, że wydawnictwa w większości nie wymagają zaawansowanych umiejętności formatowania tekstu, to istotna jest umiejętność stworzenia „czystego” tekstu zgodnego z normami języka polskiego (a więc zawierającego np. poprawnie sformatowane partie dialogowe z wykorzystaniem myślników), a nie tylko jego odmiany charakterystycznej dla Internetu9. Do wprowadzania niektórych znaków (np. cudzysłowów) warto umieć też zdefiniować poręczne skróty klawiaturowe.

Tłumacze literatury zazwyczaj korzystają z popularnego pakietu MS Office. Warto zestawić ten wynik z orientacyjnym badaniem przeprowadzonym równolegle wśród studentów, które objęło 76 studentów filologii angielskiej UMK wszystkich lat, w tym specjalności translatorycznej, i dotyczyło ich nawyków oraz kompetencji związanych z korzystaniem z komputera. Choć zestawienie tych dwóch badań, sygnalizujące możliwe różnice pomiędzy studentami a tłumaczami, ma wyłącznie charakter orientacyjny, jedną z najciekawszych różnic jest bardzo rzadkie wśród profesjonalistów, a bardzo częste wśród studentów korzystanie z dokumentów Google jako głównego edytora tekstu. Opcja ta jest popularna wśród studentów prawdopodobnie dlatego, że ta darmowa usługa umożliwia pracę na tych samych plikach na uczelni i w domu, gdzie być może korzystają z innych urządzeń, oraz pracę zespołową. Korzystający z niej na stałe studenci mogą nie znać wielu opcji, które wydają się oczywiste w przypadku tradycyjnych edytorów tekstu, typowych

9 Zob. np. Batko-Tokarz 2016. 
dla dość stacjonarnego warsztatu tłumacza literackiego. Tłumacze stosunkowo często korzystają też z zainstalowanych słowników, podczas gdy wśród studentów niezmiernie popularne są słowniki dostępne w sieci, ale słowniki, które trzeba instalować, już nie. Znowu wiąże się to zapewne $\mathrm{z}$ kosztem zakupu wersji instalacyjnej, który decydują się ponieść profesjonaliści, podczas gdy studenci zadowalają się darmowymi rozwiązaniami online, dostępnymi z każdego urządzenia.

Pośród najpowszechniejszych porad respondentów pojawiają się wskazówki dotyczące szacowania czasu potrzebnego do ukończenia przekładu. Jest to kolejna umiejętność, którą być może trudno wyćwiczyć w kontekście akademickim, gdzie studenci zazwyczaj przekładają stosunkowo krótkie teksty, dobrane pod kątem różnorodności i możliwości szybkiego sprawdzenia. Zlecenie pełnowymiarowego przekładu może być trudne wobec innych obowiązków studenta. Można sobie jednak wyobrazić ćwiczenia pozwalające na monitorowanie dziennego „urobku” studenta-tłumacza przy dłuższym przekładzie, na przykład poprzez podgląd dokumentu udostępnianego na bieżąco w sieci i sprawdzanie, na ile udaje się realizować założony przez studenta harmonogram. Praca z dłuższymi tekstami daje też możliwość ćwiczenia umiejętności sprawnego poruszania się po rozległym pliku, która sprzyja stworzeniu systemu własnych oznaczeń i umiejętności ich sprawnego odszukiwania, by móc łatwo wprowadzać zmiany w przekładzie (na przykład z powodu podmiany wersji pliku źródłowego przez zleceniodawcę).

Wśród wskazówek dla młodych tłumaczy, jakie pojawiły się w toku ankiety, można wreszcie wymienić cztery kwestie. Pierwsze zalecenie, dotyczące kopii zapasowych, warto zestawić z używaniem przez wielu studentów dokumentów Google znajdujących się w chmurze i zapisywanych automatycznie; również pisząc prace dyplomowe, prawdopodobnie nabywają oni nawyku tworzenia kopii bezpieczeństwa, a zatem ten aspekt pracy tłumacza literackiego powinien być im znany. Drugie zalecenie, ćwiczenie ergonomicznej organizacji miejsca pracy i samej pracy, choć bardzo istotne, w warunkach uczelni może nastręczać problemów, zwłaszcza ze względu na dość krótkie bloki zajęciowe. Liczba używanych na raz źródeł i aplikacji powoduje, że ważna jest także umiejętność ergonomicznego zarządzania wieloma otwartymi na raz oknami, programami czy materiałami przeglądanymi w Internecie. Od strony technicznej warto rozważyć choćby zademonstrowanie studentom korzyści z konfiguracji kilku ekranów i zewnętrznej klawiatury. Natomiast jak najbardziej możliwe jest kształcenie krytycyzmu wobec źródeł, co również postulują tłumacze, oraz dokładne zaznajamianie studentów z oprogramowaniem; warto tu rozważyć naukę o podstawowych zasadach tworzenia 
poprawnego, „czystego” tekstu, a stosowanie wyszukanych formatów tekstu raczej odradzać niż go uczyć.

\section{Literatura}

Austermuehl F., 2012, Using concept mapping and the web as corpus to develop terminological competence among translators and interpreters, „Translation Spaces”, 1, s. 54-80.

Austermuehl F., 2013, Future (and not-so-future) trends in the teaching of translation technology, „Revista Tradumàtica: tecnologies de la traducció", 11, s. 326-337.

Batko-Tokarz B., 2016, Nowa interpunkcja w nowych mediach?!, [w:] Język a media: zjawiska językowe we współczesnych mediach, B. Skowronek, E. Horyń, A. Walecka-Rynduch (red.), Kraków, s. 205-221.

Biau-Gil J. R., Pym A., 2006, Technology and translation (a pedagogical overview), [w:] Translation Technology and its Teaching, A. Pym, A. Perestrenko, B. Starink (red.), Tarragona, s. 5-19.

Fulford H., Granell-Zafra J., 2004, The uptake of online tools and web-based language resources by freelance translators: Implications for translator training, professional development, and research, [w:] Proceedings of the Second International Workshop on Language Resources for Translation Work, Research and Training, E. Y. Rodrigo (red.), Stroudsburg, s. 50-60.

Fulford H., Granell-Zafra J., 2005, Translation and technology: a study of UK freelance translators, „Journal of Specialised Translation”, 4, s. 2-17.

Guttfeld D., 2018, Tłumacze literaccy: realia i warsztat pracy, „Rocznik Przekładoznawczy Studia nad teorią, praktyką i dydaktyką przekładu”, 13, s. 83-97.

Hutchins J., 1998, The origins of the translator's workstation, „Machine Translation", 13, s. 287-307.

Landers C., 2001, Literary translation: a practical guide, Clevedon.

Pisarska A., Tomaszkiewicz T., 1998, Współczesne tendencje przekładoznawcze, Poznań.

Somers H. (red.), 2003, Computers and translation: a translator's guide, Amsterdam.

Sikora I., 2013, Polish translators' workstation: On the usage and adoption of computer-assisted translation tools with some implications for translators' training, [w:] Translator and the Computer, T. Piotrowski, Ł. Grabowski (red.), Wrocław, s. 11-33. 
Sin-Wai C. (red.), 2014, Routledge encyclopedia of translation technology, New York.

\section{The literary translator's workstation: a questionnaire-based survey Summary}

The article reports the results of a questionnaire-based survey conducted among translators of literary texts working from or into Polish. The focus is on the translator's workstation, i.e., the use of computers, covering both hardware and software adjustments conducive to literary translation. The use of text editing software and its particular functions is described with teaching literary translation in mind. Recommendations include the focus on monitoring one's pace of work, developing a system for taking notes and marking the text of long translations for future reference, effective arrangement of multiple tabs and windows, handling comments and review options.

Keywords: literary translation, survey, translator's workstation 